\title{
Molecular characterization of Tasmanian aquabirnaviruses from 1998 to 2013
}

\author{
Peter G. Mohr*, Nicholas J. G. Moody, Lynette M. Williams, John Hoad, \\ Mark St. J. Crane
}

CSIRO Australian Animal Health Laboratory, 5 Portarlington Rd, East Geelong, Victoria 3220, Australia

\begin{abstract}
Tasmanian aquabirnaviruses (TABVs) have been isolated intermittently since 1998 from healthy Atlantic salmon Salmo salar and rainbow trout Oncorhynchus mykiss farmed in Macquarie Harbour, Tasmania, Australia. However, beginning in 2011, TABVs have been isolated from rainbow trout in association with mortality events. To determine if recent molecular changes in TABV were contributing to increased mortalities, next generation sequencing was undertaken on 14 TABVs isolated from 1998 to 2013. Sequencing of both genome segments and analysis of the 5 viral proteins they encode revealed that minimal changes had occurred in the past $15 \mathrm{yr}$. Of the amino acid changes detected only 1 , alanine to aspartic acid at position 139 of the minor structural VP3 protein, was unique to the recent disease events. The most dramatic changes observed were in the length of the non-structural VP5 protein varying from 43 to 133 amino acids. However, the amino acid substitution in VP3 and variable VP5 length were unlikely to have resulted in increased TABV pathogenicity. The genome of a novel Australian aquabirnavirus, Victorian trout aquabirnavirus (VTAB) was also sequenced and compared to TABV isolates.
\end{abstract}

KEY WORDS: Aquabirnavirus · Genome · Atlantic salmon · Rainbow trout · Australia Resale or republication not permitted without written consent of the publisher

\section{INTRODUCTION}

The Aquabirnavirus genus of the viral family Birnaviridae consists of viruses present in a diverse array of freshwater and marine fish and some invertebrates from broad geographic locations (Reno 1999). Infectious pancreatic necrosis virus (IPNV) is the type species of aquabirnavirus that cause significant disease, particularly in farmed salmonids (Roberts \& Pearson 2005). The pathogenicity of isolates vary dramatically, with those not pathogenic to salmonids being named as aquabirnaviruses, to be distinguished from IPNV (Hill \& Way 1995). Traditionally the typing of aquabirnaviruses has been based on serological relationships, with serotypes A1-A9 and B1 (Hill \& Way 1995). However, more recently a classification system of 7 genogroups has become established based on the viral protein, VP2 (Blake et al. 2001, Cutrín et al. 2004, Nishizawa et al. 2005).
The aquabirnavirus genome consists of bisegmented, double-stranded RNA (dsRNA). Segment A has 2 partially overlapping open reading frames (ORFs). The larger ORF encodes a polyprotein $\left(\mathrm{NH}_{2}-\right.$ pVP2-VP4-VP3-COOH) that is cleaved to produce proteins pVP2, VP3 and VP4 (Petit et al. 2000). Upon maturation, VP2 is the major capsid structural protein, VP3 is a minor capsid structural protein and VP4 is a protease (Delmas et al. 2012). The smaller ORF encodes VP5, a non-structural anti-apoptotic protein (Hong et al. 2002). Segment B has a single ORF that encodes VP1, an RNA-dependent RNA polymerase responsible for replication (Duncan et al. 1991).

In 1998, the first aquabirnavirus isolate from Australia, TAB98, was isolated from 'pinhead' Atlantic salmon Salmo salar samples collected during health surveillance in Macquarie Harbour, Tasmania (Crane et al. 2000). Tasmanian aquabirnaviruses (TABVs) have subsequently been isolated from sev- 
eral other healthy wild and farmed fish species inhabiting Macquarie Harbour. These viruses were collected from fish with no overt signs of disease and were not detected elsewhere in Tasmania. The nucleotide sequence for both segments of the original isolate, TAB98, were determined by Davies et al. (2010). Based on this sequence, TAB98 was found to cluster within Genogroup 5 along with New Zealand aquabirnaviruses that had been isolated from healthy Chinook salmon Oncorhynchus tshawtscha. Genogroup 5 consists of isolates from diverse geographical and host ranges such as pathogenic IPNV Sp116 isolated from Atlantic salmon in Norway (Shivappa et al. 2004).

A second novel aquabirnavirus was isolated, in 2010, from rainbow trout at a freshwater hatchery in Victoria (McCowan et al. 2015). The isolation of Victorian trout aquabirnavirus (VTAB) from the skin of dead female fingerlings was the first detection of an aquabirnavirus from mainland Australia. Based on limited sequence analysis of a 738 bp region of $\mathrm{pVP} 2$, which shared less than $80 \%$ identity with TABV and IPNV isolates, the authors described VTAB as a novel aquabirnavirus, as it was genetically and phylogenetically distinct from known aquabirnaviruses. The role of VTAB in the disease event in 2010 is unclear and the virus has not been detected since.

Through the Tasmanian Salmonid Health Surveillance Program, more than 40 isolations of TABV from farmed Atlantic salmon $S$. salar and rainbow trout $O$. mykiss in Macquarie Harbour has occurred between 1998 and 2013. Prior to 2011, isolates were obtained from healthy fish as part of the routine surveillance program. However, from 2011, TABV has been isolated on several occasions from diseased rainbow trout from this location. In this study, next generation sequencing (NGS) was undertaken to generate consensus sequences for selected TABV isolates, from 1998 to 2013, to identify any molecular changes that may have occurred during that period and their potential contribution to pathogenicity. Representative isolates were selected based on the year isolated, host species and whether healthy or diseased fish. The genome of the novel VTAB was also sequenced to allow greater comparison with TABV isolates.

\section{MATERIALS AND METHODS}

\section{Viruses}

More than 40 TABVs have been isolated from Macquarie Harbour, confirmed by diagnostic RT-PCR
(Davies et al. 2010) and amplicon sequencing, since the original isolation of TAB98 from farmed Atlantic salmon in 1998 (Crane et al. 2000). In 1998, after the initial isolation, a survey of wild fish in Macquarie Harbour identified TABV in several species, including Morid cod (Pseudophycis sp.). However, most TABV isolates up to 2011 have predominantly been isolated from fish health surveillance program samples of farmed Atlantic salmon and rainbow trout. No TABVs were isolated for a $4 \mathrm{yr}$ period between 2003 and 2006. From late 2011 to 2013, TABVs were isolated from farmed rainbow trout populations that had exhibited increased mortalities. Fourteen TABV isolates from the previous $15 \mathrm{yr}$ were cultured in chinook salmon embryo (CHSE-214) or bluegill fry (BF2) cells until near $100 \%$ cytopathic effect (CPE) was observed before harvest. In addition, VTAB isolated from diseased farmed rainbow trout in 2010 in the rainbow trout gonad cell line, RTG-2 (McCowan et al. 2015), was also included. Isolates with passage history are listed in Table 1.

\section{Nucleic acid extraction}

Infected cell culture supernatants were clarified by centrifugation $(425 \times g)$ for $10 \mathrm{~min}$. For each isolate, the supernatant was decanted from the cell debris pellet and filtered $(0.45 \mu \mathrm{m})$ before high speed centrifugation $(103900 \times g)$ for $3 \mathrm{~h}$. The viral pellet was re-suspended in $300 \mu$ phosphate-buffered saline (PBSA, pH 7.4). For random-primer conventional PCR, $140 \mu \mathrm{l}$ of viral pellet was treated at $37^{\circ} \mathrm{C}$ with $100 \mathrm{U}$ RNase $\mathrm{I}_{\mathrm{f}}$ (New England Biolabs) for $16 \mathrm{~h}$ to reduce the CHSE-214 RNA content. Total nucleic acid was extracted using the QIAamp viral RNA mini kit (QIAGEN) and eluted in $30 \mu \mathrm{l}$. Co-extracted CHSE-214 genomic DNA was removed from $10 \mu \mathrm{l}$ of the extracted nucleic acid by rigorous treatment at $37^{\circ} \mathrm{C}$ with $30 \mathrm{U}$ of the Turbo DNA-free Kit (Ambion). For specific-primer conventional RT-PCR, total nucleic acid was extracted from $140 \mu \mathrm{l}$ of re-suspended viral pellet or clarified viral culture supernatant with the QIAamp viral RNA mini kit and eluted in $50 \mu l$.

\section{Random PCR}

The random PCR method to obtain complementary DNA (cDNA) from viral dsRNA was based on the sequence independent single primer amplification (SISPA) method described by Rosseel et al. 
Table 1. Percent identity of Tasmanian aquabirnaviruses (TABV) and Victorian trout aquabirnavirus (VTAB) nucleotide sequences in comparison to the TAB98 isolate, the first aquabirnavirus isolated from Atlantic salmon in Australia. Segment A and B refers to the aquabirnavirus genome consisting of bisegmented, double-stranded RNA. Virus was isolated from healthy $(\mathrm{H})$ or diseased (D) fish; for each isolate the first 2 digits represent the year of isolation and the final 5 digits refer to the case number. 'Passage history' refers to the number of passages in fish cell lines: chinook salmon embryo (CHSE-214), bluegill fry (BF-2), epithelioma papulosum cyprini (EPC), and rainbow trout gonad cell line (RTG-2). TAB98 nucleotide sequences obtained from GenBank accession EU672429 for Segment A and EU672430 for Segment B; the number of nucleotide differences for Segment A and B compared to TAB98 are given in brackets

\begin{tabular}{|c|c|c|c|c|c|c|}
\hline Virus & Fish species & Passage history & $\begin{array}{l}\text { Segment A } \\
\text { (2942 bp) }\end{array}$ & $\begin{array}{c}\text { GenBank } \\
\text { accession } \\
\text { (Segment A) }\end{array}$ & $\begin{array}{l}\text { Segment B } \\
(2605 \text { bp })\end{array}$ & $\begin{array}{c}\text { GenBank accession } \\
\text { (Segment B) }\end{array}$ \\
\hline \multicolumn{7}{|l|}{ TABV } \\
\hline 98-00208 (H) & Morid cod & CHSE-214 ×3 & $99.8 \%(5)$ & KP268650 & $99.8 \%(6)$ & KP268665 \\
\hline 01-01282 (H) & Rainbow trout & CHSE-214 $\times 3$ & $99.6 \%(13)$ & KP268651 & $99.4 \%(15)$ & KP268666 \\
\hline 02-00229 (H) & Atlantic salmon & CHSE-214 ×6 & $99.5 \%(16)$ & KP268652 & $99.5 \%(13)$ & KP268667 \\
\hline 07-01693 (H) & Rainbow trout & CHSE- $214 \times 4$ & $99.2 \%(24)$ & KP268653 & $99.2 \%(20)$ & KP268668 \\
\hline 08-03923 (H) & Rainbow trout & BF $-2 \times 2$ & $98.9 \%(32)$ & KP268654 & $99.3 \%(17)$ & KP268669 \\
\hline 08-04494 (H) & Atlantic salmon & $\begin{array}{c}\text { BF- } 2 \times 2 / \\
\text { CHSE-214 } \times 2\end{array}$ & $99.0 \%(30)$ & KP268655 & $99.2 \%(21)$ & KP268670 \\
\hline 09-01031 (H) & Atlantic salmon & $\begin{array}{c}\text { EPC } \times 2 / \\
\text { CHSE- } 214 \times 2\end{array}$ & $99.1 \%(27)$ & KP268656 & $99.3 \%(18)$ & KP268671 \\
\hline 09-01288 (H) & Rainbow trout & CHSE-214 $\times 3$ & $98.9 \%(31)$ & KP268657 & $99.2 \%(21)$ & KP268672 \\
\hline $10-00221(\mathrm{H})$ & Atlantic salmon & CHSE-214 $\times 4$ & $98.8 \%(35)$ & KP268658 & $99.1 \%(23)$ & KP268673 \\
\hline $10-00224(\mathrm{H})$ & Rainbow trout & CHSE-214 $\times 4$ & $98.8 \%(34)$ & KP268659 & $99.3 \%(18)$ & KP268674 \\
\hline $11-04076(\mathrm{H})$ & Atlantic salmon & CHSE-214 ×2 & $98.8 \%(35)$ & KP268660 & $99.0 \%(25)$ & KP268675 \\
\hline $11-04755$ (D) & Rainbow trout & CHSE- $214 \times 2$ & $98.8 \%(34)$ & KP268661 & $99.0 \%(25)$ & KP268676 \\
\hline $11-04973$ (D) & Rainbow trout & CHSE- $214 \times 2$ & $98.8 \%(35)$ & KP268662 & $99.0 \%(26)$ & KP268677 \\
\hline 13-03567 (D) & Rainbow trout & CHSE- $214 \times 1$ & $98.8 \%(34)$ & KP268663 & $99.1 \%(23)$ & KP268678 \\
\hline $\begin{array}{l}\text { VTAB } \\
10-04677\end{array}$ & Rainbow trout & RTG- $2 \times 2$ & $79.5 \%(603)$ & KP268664 & $81.3 \%(487)$ & KP268679 \\
\hline
\end{tabular}

(2011, 2013). RNase- and DNase-treated nucleic acid $(7 \mu \mathrm{l})$ was heat-denatured in the presence of $2.5 \mu \mathrm{M}$ random primer (FR20RV-12N) at $95^{\circ} \mathrm{C}$ for 5 min before quenching on ice. After the addition of $2 \mu$ l Superscript III/RNaseOUT enzyme mix and reaction mix (Superscript III first-strand synthesis supermix, Invitrogen) to a final volume of $20 \mu \mathrm{l}$, first-strand cDNA was synthesized. To first-strand cDNA, 5U Klenow and reaction buffer (Promega) were added with $200 \mu \mathrm{M}$ dNTPs, $1 \mu \mathrm{M}$ FR20RV$12 \mathrm{~N}$ and molecular grade water to a final volume of $30 \mu \mathrm{l}$, before second-strand cDNA synthesis. To amplify the randomly generated DNA, $2 \mu \mathrm{M}$ FR20RV and Phusion High-fidelity PCR master mix with HF buffer (NEB) were added to $5 \mu$ secondstrand cDNA to a final volume of $20 \mu \mathrm{l}$. First- and second-strand cDNA synthesis and cDNA amplification cycling conditions are described in Table 2. The amplified DNA was quantified with the Qubit dsDNA HS assay kit (Invitrogen) before $150 \mathrm{ng}$ was purified of primers and random-primed amplicons shorter than approx. 250 bp with 0.6× AMPure XP beads (Agencourt). The eluted DNA was quantified by Qubit.

\section{Specific RT-PCR}

Specific RT-PCR primers were designed to amplify Segments A and B by conventional PCR for next generation sequencing (Table 2). In $25 \mu \mathrm{l}$ reactions, the Superscript III One-Step RT-PCR System with Platinum Taq High Fidelity (Life Technologies) with $180 \mathrm{nM}$ of each primer was used to amplify the desired amplicons from $2 \mu$ total nucleic acid. Amplicons were visualised after electrophoresis on SYBR Safe stained 1.5\% agarose gels, excised and purified using the QIAquick gel extraction kit (Qiagen). For next generation sequencing, purified Segment A and B amplicons for each isolate were quantified by NanoDrop before being combined in a 1:1 ratio and the mixed segments quantified by Qubit.

The complete VP5 ORF for each isolate was amplified by conventional PCR with Superscript III Onestep RT-PCR with Platinum Taq (Life Technologies) and specific primers (Table 2). Each amplicon was purified by the QIAquick gel extraction kit and Sanger-sequenced using the forward and reverse primers by direct product sequencing using the 
Table 2. PCR primers and conditions used in this study of Tasmanian aquabirnaviruses (TABV) and Victorian trout aquabirnavirus (VTAB). SISPA: sequence independent single primer amplification method. NA: not applicable

\begin{tabular}{|c|c|c|c|c|c|}
\hline \multirow{2}{*}{$\begin{array}{l}\text { PCR } \\
\text { Primer }\end{array}$} & \multirow[t]{2}{*}{ Sequence $\left(5^{\prime}-3^{\prime}\right)$} & \multicolumn{3}{|c|}{ PCR conditions $-{ }_{-}$} & \multirow{2}{*}{$\begin{array}{l}\text { Amplicon } \\
\text { size (bp) }\end{array}$} \\
\hline & & Cycles & Time & Temp $\left({ }^{\circ} \mathrm{C}\right)$ & \\
\hline \multicolumn{6}{|c|}{ Random PCR SISPA } \\
\hline \multirow{13}{*}{$\begin{array}{l}\text { FR20RV }-12 \mathrm{~N}^{\mathrm{a}} \\
\text { FR20RV }^{\mathrm{a}}\end{array}$} & GCC GGA GCT CTG CAG ATA TCN NNN NNN NNN NN & \multicolumn{3}{|c|}{ First-strand cDNA } & \multirow[t]{13}{*}{ NA } \\
\hline & \multirow{12}{*}{ GCC GGA GCT CTG CAG ATA TC } & $1 \times$ & $10 \min$ & 25 & \\
\hline & & & $50 \mathrm{~min}$ & 50 & \\
\hline & & & $5 \mathrm{~min}$ & 85 & \\
\hline & & Second & and $\mathrm{cDN}$ & & \\
\hline & & $1 \times$ & $60 \mathrm{~min}$ & 37 & \\
\hline & & & $10 \mathrm{~min}$ & 75 & \\
\hline & & cDNA- & lificatior & & \\
\hline & & $1 \times$ & $30 \mathrm{~s}$ & 98 & \\
\hline & & $40 x$ & $15 \mathrm{~s}$ & 98 & \\
\hline & & & $30 \mathrm{~s}$ & 48 & \\
\hline & & & $2 \mathrm{~min}$ & 72 & \\
\hline & & $1 \times$ & $10 \mathrm{~min}$ & 72 & \\
\hline \multicolumn{6}{|c|}{ TABV SegA RT-PCR } \\
\hline TABV-SegAFor & CAA CCA CAA AAT CTA TAT CAA TGC AAG & $1 \times$ & $\begin{array}{l}30 \min \\
2 \min \end{array}$ & $\begin{array}{l}50 \\
94\end{array}$ & \multirow[t]{5}{*}{2971} \\
\hline \multirow[t]{4}{*}{ TABV-SegARev } & \multirow[t]{4}{*}{ GAT CGG TCA GGA AAG AGA GTA G } & $40 x$ & $30 \mathrm{~s}$ & 94 & \\
\hline & & & $30 \mathrm{~s}$ & 52 & \\
\hline & & & $3 \min$ & 68 & \\
\hline & & $1 \times$ & $7 \mathrm{~min}$ & 68 & \\
\hline \multicolumn{6}{|c|}{ TABV SegB RT-PCR } \\
\hline TABV-SegBFor & ACC ACG ACT GTT TAT GTA TGC AC & \multirow{2}{*}{\multicolumn{3}{|c|}{ As per TABV SegA RT-PCR }} & 2648 \\
\hline TABV-SegBR2 & CTG ATG AGT CCA TCC AGG TC & & & & \\
\hline \multicolumn{6}{|c|}{ TABV SegA VP5 RT-PCR } \\
\hline \multirow[t]{2}{*}{ TABV-AF2 } & \multirow[t]{2}{*}{ AGC CCT TTC TAA CAA ACA ACC AC } & \multirow[t]{2}{*}{$1 \times$} & $30 \mathrm{~min}$ & 50 & \multirow[t]{6}{*}{471} \\
\hline & & & $2 \mathrm{~min}$ & 94 & \\
\hline \multirow[t]{4}{*}{$\mathrm{TABPa} \mathrm{R}^{\mathrm{b}}$} & \multirow[t]{4}{*}{ GAC ATC AGG CTG TTG TAG G } & $40 x$ & $30 \mathrm{~s}$ & 94 & \\
\hline & & & $30 \mathrm{~s}$ & 53 & \\
\hline & & & $45 \mathrm{~s}$ & 68 & \\
\hline & & $1 \times$ & $7 \mathrm{~min}$ & 68 & \\
\hline \multicolumn{6}{|c|}{ VTAB SegA RT-PCR } \\
\hline VAB-SegAFor & CAT GAA CAC AAA CAA AGC AAC CG & As per & V SegA & Г-PCR & 2945 \\
\hline TABV-SegARev & As above & (but 50 & nnealing & emperature) & \\
\hline VTAB SegB RT-1 & & & & & \\
\hline VAB-SegBFor & ACC ACG ACT GTT TAC GTA TGC AC & As per & V S SegA & Г-PCR & 2656 \\
\hline VAB-SegBRev & CGG TGT TGA GTC CAG TCA TGT C & (but 50 & nnealing & emperature) & \\
\hline VTAB SegA VP5 & PR & & & & \\
\hline TABV-AF3 & GAG GAG CTC TCC GTC GATG & As per & SV SegA & P5 RT-PCR & 497 \\
\hline TABPa8R ${ }^{b}$ & As above & (but 50 & nnealing & emperature) & \\
\hline${ }^{\mathrm{a}}$ Rosseel et al. (2 & ${ }^{b}$ Blake et al. (2001) & & & & \\
\hline
\end{tabular}

BigDye Terminator v3.1 Cycle Sequencing chemistry and 3130xl Genetic Analyzer (Life Technologies) according to the manufacturer's instructions. Chromatogram analysis and consensus sequence generation were conducted using Geneious (Biomatters).

\section{Next generation sequencing (NGS)}

The NGS platform used in this study was the MiSeq Desktop Sequencer (Illumina). To prepare sequencing-ready libraries, 4 ng of bead-purified random-primer amplified DNA or combined Segment $\mathrm{A}$ and $\mathrm{B}$ specific-primer amplified DNA were fragmented and tagged by the Nextera XT DNA
Sample Preparation Kit (Illumina) according to the manufacturer's instructions. The quantity of each purified DNA library was assessed by Qubit and the average fragment size determined with the Bioanalyzer High Sensitivity DNA Kit (Agilent). Subsequently, 2 nM of each DNA library (up to 14 individual libraries) was denatured with $0.1 \mathrm{~N}$ sodium hydroxide and pooled before being diluted to $14 \mathrm{pM}$ in hybridization buffer. The pooled denatured DNA library was sequenced using an Illumina MiSeq Reagent Kit v2 (300 cycle) with MiSeq Control Software (Illumina). Approximately 1 to 2 million, $150 \mathrm{bp}$ paired reads were obtained for each individual DNA library, dependent on the number of denatured libraries present in the pool added to the flow cell. 


\section{NGS sequence assembly and analysis}

Random primer tag sequences were removed from the MiSeq paired read raw data with a dedicated iPython Anaconda script. The trimmed sequences were assembled and contigs generated for Segments A and B of each isolate by read-mapping to TAB98 Segments A and B (EU672429 and EU672430) using Geneious (Biomatters). Sanger-sequenced VP5 ORF PCR amplicons were used to complete Segment A contigs before the sequence of VP1 to VP5 were determined and translated. Sequence alignments and pairwise distance calculations for the percent nucleotide and translated amino acid identity were undertaken with Geneious Alignment algorithms. All finalized sequences for TABV and VTAB Segment A and B were submitted to GenBank (Table 1). Phylogenetic analyses using the neighbor-joining method with a bootstrap consensus tree being inferred from 10000 replicates were conducted using MEGA5 (Tamura et al. 2011). Evolutionary distances were calculated using the Tamura-Nei model.

\section{RESULTS}

Segments A and B of TABV isolates 98-00208 and 01-01282 that covered all ORFs were assembled from SISPA random-primer PCR sequences. Each segment had an average coverage of $>3000 \times$. Comparison of the nucleotide sequences for each segment from both isolates with TAB98 revealed $>99.4 \%$ identity, despite isolation from different fish species and up to $3 \mathrm{yr}$ separation in isolation date (Table 1). Based on the high sequence similarity observed between these isolates, specific-primer Segment A and B RT-PCRs were performed on the remaining 12 isolates before NGS. The specific-primer segment RT-PCR approach was also performed to confirm the TABV 98-00208 genome sequence; the assembled sequences were identical to those obtained by SISPA random RTPCR. The specific segment amplification approach resulted in average segment coverages ranging from 8900 to $83000 \times$ for the 13 isolates sequenced. The final Segment A and B sequences provided complete coverage of the 3 ORFs and represented $>94 \%$ of each genome, but each segment lacked $\sim 150 \mathrm{bp}$ of sequence that include the $5^{\prime}$ and $3^{\prime}$ termini.

Nucleotide alignments and percent identity calculation for both Segments A and B with the original TAB98 showed a high degree of similarity ( $\geq 98.8 \%)$ for all the isolates sequenced (Table 1). Interestingly, despite TABV 13-03567 being isolated from rainbow trout $15 \mathrm{yr}$ after the original TAB98 isolation from Atlantic salmon, Segments A and B shared 98.8 and 99.1\% nucleotide identity, respectively. The TABV 11-04973 isolate had the highest number of nucleotide differences (61) of the $5547 \mathrm{bp}$ of the genome that was compared with TAB98, a difference of only $1.1 \%$.

In comparison to TAB98, less than $1.5 \%$ difference in amino acid (aa) sequences was identified between VP1, pVP2, VP3 and VP4 of the 14 TABV isolates sequenced (Table 3 ). In 1998, only 4 aa differences $(0.2 \%)$ were detected between the original TAB98 isolate from Atlantic salmon and the wild cod isolate (98-00208). The latest isolate sequenced, TABV 1303567, had a total of 18 aa differences $(1.0 \%)$ when compared to TAB98. The largest difference observed in the VP1 protein (844 aa) was a total of $7 \mathrm{aa}$, found in isolate TABV 09-01288, 10-00221 and 11-04973. Regarding the other Segment A encoded proteins, 2 aa differences in VP4, 3 in VP3 and 5 in VP2 were the most detected in the TABV isolates sequenced (selected from the $15 \mathrm{yr}$ time period).

The greatest variation in the VP5 amino acid sequence was 6 aa differences in TABV 08-03923, 11-04076 and 11-04755 that equated to less than a $5 \%$ change in sequence (Table 3 ). The length of the translated VP5 protein, however, varied dramatically. TAB98 and TABV 98-00208 had a VP5 protein encoded by 133 aa whereas 01-01282 and 02-00229 were truncated to just 43 aa due to a premature stop codon. A different premature stop codon also truncated VP5 of the other 11 TABVs (isolated from 2007 to 2013) to 128 aa. Sanger sequencing of the entire VP5 ORF of the 14 isolates confirmed the premature stop codons and the aa differences that had been identified.

Single IPNV isolates representing Genogroups 1 to 6 and a marine birnavirus representing Genogroup 7 were compared at the protein level with the most recent TABV isolate 13-03567 (Table 4). As expected, the highest identity was with Genogroup 5 as described by Davies et al. (2010). Isolate 13-03567 when compared with IPNV 1146 from Genogroup 5 had $94 \%$ or greater identity with viral proteins VP1 to VP4 and $81.3 \%$ for VP5. Genogroups 1 and 6 had the most aa changes for $\mathrm{pVP} 2$ to VP4 when compared with isolate 13-03567. Phylogenetic analysis of pVP2 nucleotide sequences was conducted due to VP2 encoding the major capsid protein that determines host range and has the greatest number of aquabirnavirus sequences (from all 7 genogroups) available on GenBank. The pVP2 of all 14 TABV isolates clearly clustered phylogenetically into 1 distinct node 
Table 3. Percent identity of Tasmanian aquabirnaviruses (TABV) and Victorian trout aquabirnavirus (VTAB) proteins in comparison to the TAB98 isolate, the first aquabirnavirus isolated from Atlantic salmon in Australia. TAB98 protein sequences obtained from GenBank accession EU672430 for the viral protein VP1 and EU672429 for VP2 to VP5. Numbers in brackets indicate the number of amino acid (aa) differences compared to TAB98

\begin{tabular}{|c|c|c|c|c|c|c|}
\hline Virus & $\begin{array}{l}\text { Fish } \\
\text { species }\end{array}$ & $\begin{array}{l}\text { VP1 (\%) } \\
\text { (844 aa) }\end{array}$ & $\begin{array}{c}\text { pVP2 (\%) } \\
\text { (449 aa) }\end{array}$ & $\begin{array}{l}\text { VP3 (\%) } \\
(217 \text { aa) }\end{array}$ & $\begin{array}{l}\text { VP4 (\%) } \\
\text { (252 aa) }\end{array}$ & $\begin{array}{l}\text { VP5 (\%) } \\
\text { (133 aa) }\end{array}$ \\
\hline \multicolumn{7}{|l|}{ TABV } \\
\hline 98-00208 & Morid cod & $99.8(2)^{\mathrm{a}}$ & $99.8(1)$ & $99.5(1)$ & $100(0)$ & $100(0)^{\mathrm{b}}$ \\
\hline 01-01282 & Rainbow trout & $99.6(3)$ & $99.3(3)$ & $99.5(1)$ & $100(0)$ & $97.7(1)^{\mathrm{c}}$ \\
\hline 02-00229 & Atlantic salmon & $99.5(4)$ & $99.1(4)$ & $99.5(1)$ & $100(0)$ & $97.7(1)^{\mathrm{c}}$ \\
\hline $07-01693$ & Rainbow trout & $99.5(4)$ & 98.9. (5) & $99.5(1)$ & $99.6(1)$ & $98.4(2)^{\mathrm{a}}$ \\
\hline $08-03923$ & Rainbow trout & $99.3(6)$ & $99.3(3)$ & $99.1(2)$ & $99.6(1)$ & $95.3(6)^{\mathrm{a}}$ \\
\hline 08-04494 & Atlantic salmon & $99.3(6)$ & $99.1(4)$ & $99.1(2)$ & $99.6(1)$ & $96.9(4)^{\mathrm{a}}$ \\
\hline 09-01031 & Atlantic salmon & $99.5(4)$ & $98.9(5)$ & $99.5(1)$ & $99.6(1)$ & $97.7(3)^{a}$ \\
\hline 09-01288 & Rainbow trout & $99.2(7)$ & $98.9(5)$ & $99.1(2)$ & $99.6(1)$ & $96.1(5)^{\mathrm{a}}$ \\
\hline $10-00221$ & Atlantic salmon & $99.2(7)$ & $99.3(3)$ & $98.6(3)$ & $99.6(1)$ & $96.1(5)^{\mathrm{a}}$ \\
\hline $10-00224$ & Rainbow trout & $99.3(6)$ & $98.9(5)$ & $99.1(2)$ & $99.6(1)$ & $97.7(3)^{\mathrm{a}}$ \\
\hline $11-04076$ & Atlantic salmon & $99.3(6)$ & $99.1(4)$ & $99.1(2)$ & $99.6(1)$ & $95.3(6)^{\mathrm{a}}$ \\
\hline $11-04755$ & Rainbow trout & $99.3(6)$ & $99.1(4)$ & $98.6(3)$ & $99.6(1)$ & $95.3(6)^{a}$ \\
\hline $11-04973$ & Rainbow trout & $99.2(7)$ & $99.1(4)$ & $98.6(3)$ & $99.2(2)$ & $96.9(4)^{\mathrm{a}}$ \\
\hline $13-03567$ & Rainbow trout & $99.3(6)$ & $99.1(4)$ & $98.6(3)$ & $100(0)$ & $96.1(5)^{a}$ \\
\hline \multicolumn{7}{|l|}{ VTAB } \\
\hline $10-04677$ & Rainbow trout & $89.6(88)$ & $89.8(46)$ & $80.6(42)$ & $85.3(37)$ & $66.2(45)^{\mathrm{b}}$ \\
\hline
\end{tabular}

Table 4. Percent identities between Tasmanian aquabirnavirus TABV 13-03567 and aquabirnaviruses Genogroups 1-7 for viral proteins VP1 to VP5. IPNV: infectious pancreatic necrosis virus. Numbers of amino acid (aa) differences compared to TABV 13-03567. NA: not available

\begin{tabular}{|c|c|c|c|c|c|c|c|c|c|c|c|}
\hline Aquabirnavirus & $\begin{array}{l}\text { Geno- } \\
\text { group }\end{array}$ & Species & Location & $\begin{array}{c}\text { GenBank } \\
\text { accession } \\
\text { (VP1) }\end{array}$ & $\begin{array}{l}\text { VP1 (\%) } \\
\text { (844 aa) }\end{array}$ & $\begin{array}{c}\text { GenBank } \\
\text { accession } \\
\text { (polyprotein) }\end{array}$ & $\begin{array}{c}\text { pVP2 (\%) } \\
\text { (449 аa) }\end{array}$ & $\begin{array}{l}\text { VP3 (\%) } \\
\text { (217 aа) }\end{array}$ & $\begin{array}{l}\text { VP4 (\%) } \\
\text { (252 aa) }\end{array}$ & $\begin{array}{c}\text { GenBank } \\
\text { accession } \\
\text { (VP5) }\end{array}$ & $\begin{array}{l}\text { VP5 (\%) } \\
\text { (128 аa) }\end{array}$ \\
\hline IPNV West Buxton & 1 & Trout & USA & AAC71004.1 & $89.8(86)$ & AAC71003.1 & $88.6(51)$ & $82.5(38)$ & $84.1(40)$ & AAC71002.1 & $64.3(47)$ \\
\hline IPNV 578 & 2 & Turbot & Spain & CAD32986.1 & $96.2(32)$ & CAD32970.1 & $92.7(33)$ & $87.6(27)$ & $92.9(18)$ & CAD32978.1 & $74.2(33)$ \\
\hline IPNV Canada 1 & 3 & Trout & Canada & NA & NA & AF342732_1 & $92.4(34)$ & $89.9(22)$ & $94.4(14)$ & NA & NA \\
\hline IPNV Canada 2 & 4 & Trout & Canada & NA & NA & AF342733_1 & $90.2(44)$ & $87.1(28)$ & $91.7(21)$ & AAA92627.1 & $74.2(33)$ \\
\hline IPNV 1146 & 5 & Trout & Spain & CAD32980.1 & $96.4(30)$ & CAD32964.1 & $95.3(21)$ & $94.0(13)$ & $98.4(4)$ & CAD32972.1 & $81.3(24)$ \\
\hline IPNV He & 6 & Pike & Germany & NA & NA & AF342730_1 & $86.4(61)$ & $83.9(35)$ & $84.5(39)$ & NA & NA \\
\hline Marine birnavirus Y-6 & 7 & Yellowtail & Japan & AAN04570.1 & $90.6(79)$ & AAP37161.1 & $91.8(46)$ & $83.9(35)$ & $84.1(40)$ & AАР37160.1 & $64.1(46)$ \\
\hline
\end{tabular}

within Genogroup 5 (Fig. 1). This node was clearly separate from IPNV isolates of Genogroup 5 that clustered in a separate distinct node. The only other aquabirnaviruses to cluster in the same node as the 14 TABV isolates were from Macquarie Harbour (TAB98 and TAB02) and New Zealand (NZ06 and NZ10), further supporting the Australian and New Zealand isolates having a common ancestor. Analysis of the nucleotide sequences obtained for Segments A and $\mathrm{B}$ and the translated amino acid sequences of the 5 viral proteins resulted in similar topographies (data not shown).

A comparative analysis of TABV isolates obtained from rainbow trout farms showing mortalities (1104755, 11-04973 and 13-03567) and from healthy
Atlantic Salmon (11-04076) was performed. The analysis revealed 11 loci with differing amino acids in all 5 proteins. Of these, 8 loci had the same aa present in the 3 isolates but not TABV 11-04076. However, only alanine (A) at position 139 of VP3 of the 3 isolates was unique when compared to all the other sequenced TABV isolates which had an aspartic acid (D) at this position.

The VTAB 10-04677 isolated from rainbow trout in Victoria was distinct from TABV with approx. $20 \%$ of its genome differing from that of TAB98 (Table 1). Of the 5 VTAB viral proteins, VP1 and pVP2 shared the greatest identity ( $>89 \%$ ) with TAB98, with the lowest identity (66\%) present in the 133 aa VP5 (Table 3). In comparison to representatives of each aquabirna- 
virus genogroup, VTAB was most similar to marine birnavirus Y-6 (Genogroup 7) isolated from yellowtail in Japan for proteins VP1, pVP2, VP4 and VP5 (Appendix). However, VTAB VP3 was most similar to IPNV West Buxton isolated from trout in USA (Genogroup 1). Phylogenetically analysis of pVP2 demonstrated that VTAB was distinctly different from all aquabirnavirus isolates examined, with the closest association to Genogroups 1 and 7 (Fig. 1). Similar to TABV, further phylogenetic analysis of Segment A and B and translated viral protein sequences resulted in similar topographies (data not shown).

\section{DISCUSSION}

In this study, the complete coding regions of 14 TABVs (selected from 1998 to 2013 isolations) and the novel VTAB were sequenced by NGS. To enable the assembly of the complete coding regions of Segments A and B of TABV and VTAB isolates a combination of SISPA random-primer RTPCR and specific-primer RT-PCR approaches were performed. The SISPA technique, while labour-intensive, allowed for entire dsRNA genomes to be sequenced. The method developed should be effective for the sequencing of other RNA viruses that can be cultured in vitro. However, after initial sequencing revealed that the TABV genomes being studied were highly similar, a much more rapid specific-primer RT-PCR was developed. This method was efficient and effective as the dsRNA genome being amplified was relatively short and only bisegmental. This specificprimer RT-PCR approach would be more complicated and potentially problematic if the viruses being studied had more segments (e.g. reoviruses) or the genomes were more diverse in sequence.

Discrete amino acids of the VP2 major capsid protein have been identified as key virulence factors for IPN viruses in salmonid species (Bruslind \& Reno 2000, Song et al. 2005). In addition, the reversion of a less virulent IPNV isolate to a more virulent isolate in persistently infected and stressed Atlantic salmon has been associ-

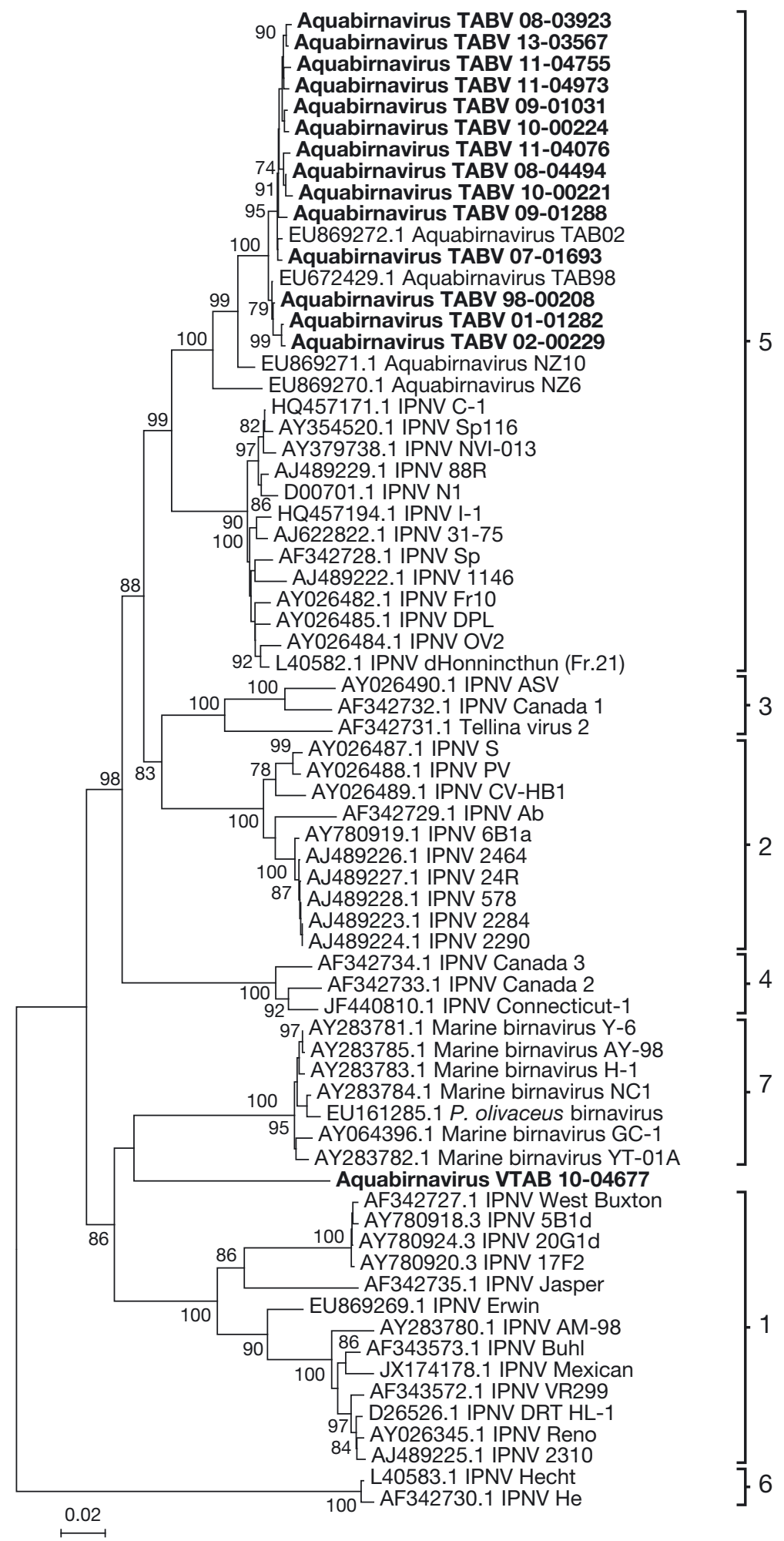

Fig. 1. Unrooted phylogenetic tree of aquabirnaviruses over the viral protein pVP2 region (1344 bp) of Segment A, inferred using the neighbor-joining method. The percentage of replicate trees in which the associated taxa clustered together in the bootstrap test (10000 replicates) are shown next to the branches (only when $>70 \%$ ). Sequences generated from this study are highlighted in bold. IPNV: infectious pancreatic necrosis virus 
ated with VP2 amino acid variations (Gadan et al. 2013). However, none of the amino acid changes detected in TABV VP2 were unique to the TABV isolates from 2011 to 2013 associated with rainbow trout disease events. The only unique change (D139A) common to the isolates associated with disease occurred in VP3, the minor internal structural protein. To date, substitutions in VP3 sequences have not been attributed to changes in aquabirnavirus virulence. It is therefore likely that a combination of factors related to the host and environment could have been sufficient to result in increased incidence of disease rather than distinct molecular changes in the virus.

The VP5 protein may be involved in anti-apoptosis (Hong et al. 2002) but has been found to be highly variable in amino acid sequence and not required for viral replication or persistence (Santi et al. 2005). The length of VP5 can vary dramatically in IPNV (i.e. 28 aa to 133 aa) but the functional significance of such changes remains unclear (Skjesol et al. 2011). The effect of the premature stop codons detected within TABV in this study are also unknown but did not correlate with the disease events of 2011 to 2013.

Within the 15 yr period of study, the TABV genomes were remarkably similar with low genetic diversity regardless of whether the isolates were from Atlantic salmon or rainbow trout. The TABV isolates sequenced from Macquarie Harbour were monophyletic and demonstrated that, thus far, only 1 viral population exists from a single ancestral origin. Therefore, the genetic diversity observed probably originated from point mutations associated with the error-prone nature of $\mathrm{RdRp}$ replication of RNA viruses without proofreading capabilities (Duffy et al. 2008). In one of the few longitudinal studies of an aquabirnavirus, low genetic diversity was also observed within IPNV in Mexico over a 6 yr period from 4 rainbow trout-producing regions (BarreraMejía et al. 2011).

The VTAB isolate was associated with deaths in freshwater rainbow trout, but it is unknown if the virus was responsible for the disease or was an opportunistic isolation from the disease investigation (McCowan et al. 2015). Intriguingly, the virus has not been isolated since 2010, and its host range is unknown. Our phylogenetic analysis indicated that the virus was distinct from TABV, and despite some relatedness to Genogroups 1 and 7 , the VTAB genome is sufficiently different to propose that the virus is the type strain for a new Genogroup 8.
Acknowledgements. We thank Ivano Broz for development of the iPython Anaconda script and the CSIRO, AAHL DSR Sequencing Laboratory for generating Sanger sequences. This research was supported by funding from Fisheries Research and Development Corporation on behalf of the Australian Government (FRDC Project 2010-032).

\section{LITERATURE CITED}

Barrera-Mejía M, Martínez S, Ortega C (2011) Genotyping of infectious pancreatic necrosis virus isolates from Mexico State. J Aquat Anim Health 23:200-206

Blake S, Ma JY, Caporale DA, Jairath S, Nicholson BL (2001) Phylogenetic relationships of aquatic birnaviruses based on the deduced amino acid sequences of genome segment A cDNA. Dis Aquat Org 45:89-102

Bruslind LD, Reno PW (2000) Virulence comparison of three Buhl-subtype isolates of infectious pancreatic necrosis virus in brook trout fry. J Aquat Anim Health 12:301-315

Crane MSJ, Hardy-Smith P, Williams LM, Hyatt AD and others (2000) First isolation of an aquatic birnavirus from farmed and wild fish species in Australia. Dis Aquat Org 43:1-14

Cutrín JM, Barja JL, Nicholson BL, Bandín I, Blake S, Dopazo CP (2004) Restriction fragment length polymorphisms and sequence analysis: an approach for genotyping infectious pancreatic necrosis virus reference strains and other aquabirnaviruses isolated from northwestern Spain. Appl Environ Microbiol 70:1059-1067

- Davies KR, McColl KA, Wang LF, Yu M, Williams LM, Crane MSJ (2010) Molecular characterisation of Australian isolates of aquatic birnaviruses. Dis Aquat Org 93:1-15

Delmas B, Mundt E, Vakharia VN, Wu JL (2012) Family Birnaviridae. In: King AMQ, Adams MJ, Carstens EB, Lefkowitz EJ (eds) Virus taxonomy. Ninth Report of the International Committee on Taxonomy of Viruses. Elsevier Academic Press, Sydney, p 499-507

Duffy S, Shackleton LA, Holmes EC (2008) Rates of evolutionary change in viruses: patterns and determinants. Nat Rev Genet 9:267-276

> Duncan R, Mason CL, Nagy E, Leong JA, Dobos P (1991) Sequence analysis of infectious pancreatic necrosis virus genome segment B and its encoded VP1 protein: a putative RNA-dependent RNA polymerase lacking the GlyAsp-Asp motif. Virology 181:541-552

- Gadan K, Sandtrø A, Marjara IS, Santi N, Munang'andu HM, Evensen O (2013) Stress-induced reversion to virulence of infectious pancreatic necrosis virus in native fry of Atlantic salmon (Salmo salar L.). PLoS ONE 8:e54656

Hill BJ, Way K (1995) Serological classification of infectious pancreatic necrosis (IPN) virus and other aquatic birnaviruses. Annu Rev Fish Dis 5:55-77

Hong JR, Gong HY, Wu JL (2002) IPNV VP5, a novel antiapoptosis gene of the Bcl-2 family, regulates McL-1 and viral protein expression. Virology 295:217-229

McCowan C, Motha J, Crane MStJ, Moody NJG, Crameri S, Hyatt AD, Bradley T (2015) Isolation of a novel aquatic birnavirus from rainbow trout Oncorhynchus mykiss in Australia. Dis Aquat Org 114:117-125

Nishizawa T, Kinoshita S, Yoshimizu M (2005) An approach for genogrouping of Japanese isolates of aquabirnaviruses in a new genogroup, VII, based on the VP2/NS junction region. J Gen Virol 86:1973-1978

> Petit S, Lejal N, Huet JC, Delmas B (2000) Active residues 
and viral substrate cleavage sites of the protease of the birnavirus infectious pancreatic necrosis virus. J Virol 74: 2057-2066

Reno P (1999) Infectious pancreatic necrosis and associated aquatic birnaviruses. In: Woo PTK, Bruno DW (eds) Fish diseases and disorders, Vol 3. CAB International, Wallingford, p 1-55

Roberts RJ, Pearson MD (2005) Infectious pancreatic necrosis in Atlantic salmon Salmo salar L. J Fish Dis 28: 383-390

Rosseel T, Lambrecht B, Vandenbussche F, van den Berg T, Van Borm S (2011) Identification and complete genome sequencing of paramyxoviruses in mallard ducks (Anas platyrhynchos) using random access amplification and next generation sequencing technologies. Virol J 8:463

Rosseel T, Van Borm S, Vandenbussche F, Hoffmann B, van den Berg T, Beer M, Hoper D (2013) The origin of biased sequence depth in sequence-independent nucleic acid amplification and optimization for efficient massive parallel sequencing. PLoS ONE 8:e76144
Santi N, Song H, Vakharia VN, Evensen O (2005) Infectious pancreatic necrosis virus VP5 is dispensable for virulence and persistence. J Virol 79:9206-9216

Shivappa RB, Song H, Yao K, Aas-Eng A, Evensen Ø, Vakharia N (2004) Molecular characterization of Sp serotype strains of infectious pancreatic necrosis virus exhibiting differences in virulence. Dis Aquat Org 61: 23-32

Skjesol A, Skjaeveland I, Elnaes M, Timmerhaus G and others (2011) IPNV with high and low virulence: host immune responses and viral mutations during infection. Virol J 8:396

Song H, Santi N, Eversen O, Vakharia VN (2005) Molecular determinants of infectious pancreatic necrosis virus virulence and cell culture adaptation. J Virol 79:10289-10299

Tamura K, Peterson D, Peterson N, Stecher G, Nei M, Kumar S (2011) MEGA5: molecular evolutionary genetics analysis using maximum likelihood, evolutionary, distance, and maximum parsimony methods. Mol Biol Evol 28: 2731-2739

Appendix. Percent identities between Victorian trout aquabirnavirus VTAB 10-04677 and aquabirnaviruses Genogroups 1-7 for viral proteins VP1 to VP5. Number of amino acid (aa) differences compared to VTAB 10-04677. IPNV: infectious pancreatic necrosis virus; NA: not available

\begin{tabular}{|c|c|c|c|c|c|c|c|c|c|c|c|}
\hline Aquabirnavirus & $\begin{array}{l}\text { Geno- } \\
\text { group }\end{array}$ & Species & Location & $\begin{array}{c}\text { GenBank } \\
\text { accession } \\
\text { (VP1) }\end{array}$ & $\begin{array}{l}\text { VP1 (\%) } \\
\text { (844 aa) }\end{array}$ & $\begin{array}{c}\text { GenBank } \\
\text { accession } \\
\text { (polyprotein) }\end{array}$ & $\begin{array}{c}\text { pVP2 (\%) } \\
\text { (449 aa) }\end{array}$ & $\begin{array}{l}\text { VP3 (\%) } \\
(217 \text { aa) }\end{array}$ & $\begin{array}{l}\text { VP4 (\%) } \\
(252 \mathrm{aa})\end{array}$ & $\begin{array}{c}\text { GenBank } \\
\text { accession } \\
\text { (VP5) }\end{array}$ & $\begin{array}{l}\text { VP5 (\%) } \\
\text { (133 aa) }\end{array}$ \\
\hline IPNV West Buxton & 1 & Trout & USA & AAC71004.1 & $94.2(49)$ & AAC71003.1 & $89.8(46)$ & $88.9(24)$ & $86.1(35)$ & AAC71002.1 & $75.9(32)$ \\
\hline IPNV 578 & 2 & Turbot & Spain & CAD32986.1 & $90.6(79)$ & CAD32970.1 & $89.1(49)$ & $81.1(41)$ & $84.9(38)$ & CAD32978.1 & $63.9(48)$ \\
\hline IPNV Canada 1 & 3 & Trout & Canada & NA & NA & AF342732_1 & $89.5(47)$ & $79.7(44)$ & $82.5(44)$ & NA & NA \\
\hline IPNV Canada 2 & 4 & Trout & Canada & NA & NA & AF342733_1 & $88.4(52)$ & $80.6(42)$ & $83.7(41)$ & AAA92627.1 & $66.9(44)$ \\
\hline IPNV 1146 & 5 & Trout & Spain & CAD32980.1 & $90.3(82)$ & CAD32964.1 & $90.9(41)$ & $79.3(45)$ & 84.5 (39) & CAD32972.1 & $66.9(44)$ \\
\hline IPNV He & 6 & Pike & Germany & NA & NA & AF342730_1 & $84.4(70)$ & $80.2(43)$ & $79.4(52)$ & NA & NA \\
\hline Marine birnavirus Y-6 & 7 & Yellowtail & Japan & AAN04570.1 & $95.1(41)$ & AAP37161.1 & $92.0(36)$ & $86.2(30)$ & $89.3(27)$ & AAP37160.1 & $78.2(29)$ \\
\hline
\end{tabular}

Editorial responsibility: V. Gregory Chinchar, Jackson, Mississippi, USA
Submitted: February 4, 2015; Accepted: July 3, 2015

Proofs received from author(s): August 26, 2015 